\title{
STUDIES ON THE CHEMOTHERAPY OF THE HUMAN MALARIAS. VII. THE ANTIMALARIAL ACTIVITY OF PAMAQUINE 1,2,8
}

\author{
BY ROBERT W. BERLINER, DAVID P. EARLE, JR., JOHN V. TAGGART, WILLIAM \\ J. WELCH,4 CHARLES G. ZUBROD,4 PETER KNOWLTON,4 JOHN \\ A. ATCHLEY, ${ }^{5}$ AND JAMES A. SHANNON \\ (From the Department of Medicine, New York University College of Medicine, and the \\ Research Service, Third [New York University] Medical Division, \\ Goldwater Memorial Hospital, New York City)
}

(Received for publication March 12, 1947)

Pamaquine, synthesized in 1926, was introduced in the treatment of malaria as a schizonticide. It was soon found, however, that the great schizonticidal activity which it possessed in cathemerium malaria of canaries did not obtain in the human malarias. It was shown to be relatively ineffective in acute attacks of vivax malaria and to have only minimal activity against the asexual forms of $P$. falciparum, although it did eradicate the gametocytes in this infection. In addition, the general usefulness of pamaquine was limited by the frequent occurrence of toxic effects with doses in the therapeutic range. Nonetheless, evidence was advanced favoring both a prophylactic $(1,2,3)$ and curative action (4) in vivax malaria. The toxicity of the drug and an incomplete understanding of the biology of vivax malaria led the commission on malaria of the Health Organization of the League of Nations (5) to state that its prophylactic action was not practical and to discount the work of Sinton on its curative action (4). The commission recommended that pama-

\footnotetext{
1 The work described in this paper was done under a contract, recommended by the Committee on Medical Research, between the Office of Scientific Research and Development and New York University.

2 A portion of this work was presented at the meetings of the Federation of American Societies for Experimental Biology, March 11-15, 1946, Federation Proc., 1946, 5, 165 and 207.

3 The authors express their thanks to the Malaria Study Section of the National Institute of Health for editorial assistance and for arrangements in regard to the publication of this paper. They are also grateful to the Abbott Laboratories, E. I. du Pont de Nemours and Company, Inc., E. R. Squibb and Sons, Eli Lilly and Company, Sharp and Dohme, and Wyeth, Inc., for contributing toward the publication costs.

4 Captain, MC, AUS.

${ }^{5}$ 1st Lieutenant, MC, AUS.
}

quine be used only as a gametocide in falciparum malaria.

One of the objectives of the wartime malaria program was the development of agents which would cure vivax malaria. The discovery of drugs with suppressive activity greatly in excess of that of quinacrine made it possible to study the hypothesis that increased suppressive action might be sufficient to prevent the relapses of vivax malaria. With chloroquine ( $\mathrm{SN}-7618)$ and paludrine it was possible to achieve and maintain concentrations of drug in the plasma many times that required to interrupt the acute attack and eradicate the erythrocytic parasites. True relapses of sporozoite-induced vivax malaria, however, were not eliminated. It was evident that chemotherapy directed against the tissue form of the parasite responsible for relapses (6) would require a qualitatively different action.

Independently in this country and in Great Britain, attention was directed to the older experiments which suggested that pamaquine did, indeed, have an effect on the tissue forms of vivax malaria. The experiments of James in the prophylaxis of mosquito-transmitted malaria were confirmed by Watson et al. (7). In Great Britain the effect of pamaquine, administered with quinine, in reducing the incidence of relapses in naturally acquired vivax malaria was again demonstrated (8).

Studies were undertaken in this laboratory to examine the pharmacology and toxicity of pamaquine, to determine more precisely its suppressive activity in vivax and falciparum malaria, and to explore its potentialities in the cure of mosquito-transmitted vivax malaria. The purpose of the study was not only to define the usefulness of pamaquine itself in the treatment of malaria in the human, but also to obtain information which might 
be valuable in the exploration of related compounds.

\section{SUPPRESSIVE ANTIMALARIAL ACTIVITY}

Methods. The ability of pamaquine to interrupt acute attacks of vivax and falciparum malaria was studied, using standard techniques previously described $(6,9)$. Infections with the $\mathrm{McCoy}$ strain of $P$. vivax and the $\mathrm{McCl}$ endon and Costa strains of $P$. falciparum were established by the intravenous injection of infected blood containing a standard number of parasites. Dosage schedules were designed to produce fairly uniform concentrations of pamaquine in the plasma during the fourand eight-day test periods utilized in the vivax infections and during a six-day period in falciparum infections. The results of therapy are classified in three groups: Class I, no definite effect on the course of the infection; Class II, a temporary suppression, either partial or complete, of parasitemia and/or fever; and Class III, a complete interruption of the schizogonous cycle manifested by the absence of parasitemia for 14 days (vivax) or 21 days (falciparum) followed by a positive reinoculation to demonstrate continuing host susceptibility to the infection.

Blood-induced vivax malaria. The effect of various doses of pamaquine administered for four days was observed in 14 patients with bloodinduced vivax ( $\mathrm{McCl}$ ) malaria (Table $\mathrm{I}$ ). The concentrations of drug in the plasma were determined by the method of Brodie et al. (10). Daily doses of $30 \mathrm{mg} .{ }^{6}$ or more resulted in com-

TABLE I

Relationship between daily dosage and plasma level of pamaquine and therapeutic effect in blood-induced vivax malaria (McCoy strain) Four-day test

\begin{tabular}{|c|c|c|c|c|c|}
\hline \multirow{2}{*}{ Patient } & \multirow{2}{*}{$\begin{array}{l}\text { Daily } \\
\text { dose }\end{array}$} & \multirow{2}{*}{$\begin{array}{c}\text { Mean } \\
\text { plasma } \\
\text { concen- } \\
\text { tration }\end{array}$} & \multicolumn{3}{|c|}{ Result class } \\
\hline & & & I & II & III \\
\hline $\begin{array}{l}\mathrm{Si} \\
\mathrm{Ko} \\
\mathrm{Ki} \\
\mathrm{Bi} \\
\mathrm{To} \\
\mathrm{Ca} \\
\mathrm{Me} \\
\mathrm{Ra} \\
\mathrm{Pi} \\
\mathrm{Le} \\
\mathrm{Fl} \\
\mathrm{An} \\
\mathrm{Pl} \\
\mathrm{Ow}\end{array}$ & $\begin{array}{l}\text { grams } \\
\text { (base) } \\
.09 \\
.09 \\
.09 \\
.06 \\
.06 \\
.03 \\
.03 \\
.03 \\
.02 \\
.02 \\
.01 \\
.01 \\
.004 \\
.004\end{array}$ & $\begin{array}{r}\mu g . / L \\
571 \\
422 \\
196 \\
127 \\
84 \\
114 \\
45 \\
16 \\
17 \\
25 \\
22 \\
313 \\
9 \\
2\end{array}$ & $\mathbf{x}$ & $\begin{array}{l}\mathbf{x} \\
\mathbf{x} \\
\mathbf{x} \\
\mathbf{x} \\
\mathbf{x} \\
\mathbf{x} \\
\mathbf{x} \\
\mathbf{x} \\
\mathbf{x}^{*} \\
\mathbf{x}^{*} \\
\mathbf{x}^{*} \\
\mathbf{x}^{*} \\
\mathbf{x}^{*}\end{array}$ & \\
\hline
\end{tabular}

* Partial effect on parasites.

${ }^{6}$ All dosages are recorded in terms of the free base.
TABLE II

Relationship between daily dosage and plasma level of pamaquine and therapeutic effect in blood-induced vivax malaria (McCoy strain) Eight-day test

\begin{tabular}{|c|c|c|c|c|c|}
\hline \multirow{2}{*}{ Patient } & \multirow{2}{*}{$\begin{array}{l}\text { Daily } \\
\text { dose }\end{array}$} & \multirow{2}{*}{$\begin{array}{c}\text { Mean } \\
\text { plasma } \\
\text { concen- } \\
\text { tration }\end{array}$} & \multicolumn{3}{|c|}{ Result class } \\
\hline & & & I & II & III \\
\hline $\begin{array}{l}\text { Go } \\
\mathrm{Hu} \\
\mathrm{Ru} \\
\text { No }\end{array}$ & $\begin{array}{c}\text { grams } \\
\text { (base) } \\
.09 \\
.09 \\
.02 \\
.02\end{array}$ & $\begin{array}{r}\mu g . / L \\
600 \\
147 \\
23 \\
20\end{array}$ & & $\begin{array}{l}\mathbf{x} \\
\mathbf{x}\end{array}$ & $\mathbf{x}$ \\
\hline
\end{tabular}

plete temporary suppression of both parasites and fever in every instance. Daily doses of 4-20 mg. produced partial or temporary suppression of parasitemia, except in one individual whose infection was not definitely affected by a daily dose of $4 \mathrm{mg}$. In no instance was a Class III (permanent) effect observed. The effect obtained was not as clearly related to plasma drug concentration as to the daily dose of drug.

The period of therapy was extended to eight days in four additional patients (Table II). Complete and permanent (Class III) interruption of the infection was produced in one subject who received a daily dose of $90 \mathrm{mg}$.

Blood-induced falciparum malaria. Observations on the suppressive activity of pamaquine in blood-induced falciparum (McClendon) malaria were obtained in eight individuals (Table III). The effect of $30 \mathrm{mg}$. daily for the six-day test pe-

\section{TABLE III}

Relationship between daily dosage and plasma level of pamaquine and therapeutic effect in blood-induced falciparum malaria (McClendon, strain) Six-day test

\begin{tabular}{|c|c|c|c|c|c|}
\hline \multirow{2}{*}{ Patient } & \multirow{2}{*}{$\begin{array}{c}\text { Daily } \\
\text { dose }\end{array}$} & \multirow{2}{*}{$\begin{array}{l}\text { Mean } \\
\text { plasma } \\
\text { concen- } \\
\text { tration }\end{array}$} & \multicolumn{3}{|c|}{ Result class } \\
\hline & & & I & II & III \\
\hline $\begin{array}{l}\text { V1 } \\
\text { Ga } \\
\text { Ed } \\
\text { An } \\
\text { Th } \\
\text { Wr } \\
\text { Sa } \\
\text { Wi }\end{array}$ & $\begin{array}{c}\text { grams } \\
\text { (base) } \\
.06 \\
.06 \\
.06 \\
.06 \\
.06 \\
.03 \\
.03 \\
.03\end{array}$ & $\begin{array}{c}\mu 8 . / L \\
545^{*} \\
188 \\
128 \\
95 \\
72 \\
89 \\
74 \\
36^{*}\end{array}$ & & $\begin{array}{l}\mathbf{x} \\
\mathbf{x} \\
\mathbf{x} \\
\mathbf{x} \\
\mathbf{x} \\
\mathbf{x} \\
\mathbf{x} \\
\mathbf{x}\end{array}$ & \\
\hline
\end{tabular}

* Patient received drug for only five days. 
TABLE IV

Relationship between daily dosage and plasma level of pamaquine and therapeutic effect in blood-induced falciparum malaria (Costa strain) Six-day test

\begin{tabular}{l|c|c|c|c|c}
\hline \hline & \multirow{2}{*}{$\begin{array}{c}\text { Daily } \\
\text { dose }\end{array}$} & $\begin{array}{c}\text { Mean } \\
\text { plasma } \\
\text { concen- } \\
\text { tration }\end{array}$ & \multicolumn{3}{|c}{ Result class } \\
\cline { 3 - 6 } & & & & II & III \\
\hline & $\begin{array}{c}\text { grams } \\
\text { (base) }\end{array}$ & $\mu g . / L$ & & & \\
$\mathrm{Ad}$ & .06 & 2000 & & $\mathrm{x}$ & \\
$\mathrm{Ma}$ & .06 & 174 & & $\mathrm{x}^{*}$ & \\
$\mathrm{Bu}$ & .06 & 92 & & $\mathrm{x}^{*}$ & \\
$\mathrm{Co}$ & .06 & 215 & $\mathrm{x}$ & & \\
$\mathrm{Ko}$ & .06 & 39 & $\mathrm{x}$ & & \\
\hline
\end{tabular}

* Partial effect on parasites.

riod did not differ significantly from that of $60 \mathrm{mg}$. daily. In each instance fever was temporarily interrupted and the number of parasites diminished. Parasites were temporarily absent from thick blood smears in only one case.

Similar observations were made in five patients with blood-induced falciparum malaria due to the Costa strain (Table IV). Among five patients who received $60 \mathrm{mg}$. daily for six days, two showed no effect, two partial effects, and one a temporarily complete suppression of the infection.

\section{CURATIVE ACTIVITY IN $P$. vivax INFECTIONS}

The curative activity of pamaquine in mosquito-transmitted infections with the Chesson strain of $P$. vivax was examined in two series of young white male volunteers with no past history of exposure to malaria. ${ }^{7} \mathrm{In}$ fections were established by the bite of mosquitoes infected with the Chesson strain of $P$. vivax. ${ }^{8}$ Each mosquito bit only one individual. The salivary glands of mosquitoes known to have bitten were removed by dissection and examined for the presence of sporozoites. The density of the gland infection was estimated as one to four plus. The inoculum received by each subject was recorded as the summation of the infection-densities of the mosquitoes by which he had been bitten. Thick smears were examined daily for the presence of parasites from the time of the expected termination of the prepatent period until the completion of drug therapy and thereafter at in-

${ }^{7}$ A group of 27 conscientious objectors was assembled at Goldwater Memorial Hospital through the cooperation of the American Friends Service Committee and the Selective Service Administration. Arrangements for the study conducted at the United States Disciplinary Barracks, Green Haven, New York, were made through the cooperation of the Office of the Surgeon General.

8 Many of the infected mosquitoes were furnished by Doctors Clay G. Huff and Frederick Coulston, whose assistance is gratefully acknowledged. tervals not exceeding one week. Drug therapy was instituted in primary attacks on the fourth day after the onset of fever above $100.6^{\circ} \mathrm{F}$. (rectal). In later attacks therapy was started as soon as the presence of a relapse was confirmed. Dosage regimens were designed to produce and maintain a fairly constant plasma drug concentration throughout the period of drug administration.

The reappearance of parasites at any time after the completion of drug therapy was considered to represent a relapse.

The patients in the exploratory studies conducted at Goldwater Memorial Hospital were divided into five small groups as follows:

Group I (Controls) - Quinine alone for 16 days (2 grams daily), five patients.

Group II-Quinine for 16 days (2 grams daily) and pamaquine for 14 days ( $30 \mathrm{mg}$. daily), the latter beginning on the third day of quinine therapy, four patients.

Group III-Quinacrine for six to 16 days ( 0.3 gram daily) and pamaquine for 14 days ( $30 \mathrm{mg}$. daily), the two drugs being started simultaneously, four patients.

Group IV-Quinine for 16 days (2 grams daily) and pamaquine for 14 days ( $90 \mathrm{mg}$. daily), the latter beginning on the third day of quinine therapy, nine patients.

Group V-Pamaquine for 14 days (90 mg. daily), followed by quinine for 10 days ( 2 grams daily), five patients.

A summary of the results of these experiments is given in Table V. It may be concluded from these data that a combination of pamaquine and quinine has a curative action in Chesson vivax malaria, providing the drugs are administered concurrently in high dosage and for a long period of time. The groups are too small and the variables too many, to warrant further analysis of the data.

Other studies were conducted by the University of Chicago group at Stateville (11) and by ourselves at the U. S. Disciplinary Barracks, Green Haven, in order to determine more accurately the quantitative nature of this curative action.

The patients in the Green Haven studies were divided into two groups. Twelve volunteers were treated in their primary attacks as well as in each subsequent relapse, with 2 grams of quinine daily for 16 days. The primary attacks in 18 subjects were treated with quinine, 2 grams daily for 16 days, plus pamaquine, $60 \mathrm{mg}$. daily for 14 days, beginning on the third day of quinine therapy. Each subsequent attack in these individuals was treated with the same regimen. This dosage of 
TAB̈L்̀ Vे

Curative effect of pamaquine in primary attacks of sporozoite-induced vivax malaria (Chesson strain)

\begin{tabular}{|c|c|c|c|c|c|}
\hline \multirow{2}{*}{ Patient } & \multirow{2}{*}{ Inoculum* } & \multicolumn{2}{|c|}{ Mean drug concen- } & \multirow{2}{*}{$\begin{array}{l}\text { Days to } \\
\text { relapse }\end{array}$} & \multirow{2}{*}{$\begin{array}{c}\text { Observa- } \\
\text { tion } \\
\text { period } \\
\text { (negative } \\
\text { cases) }\end{array}$} \\
\hline & & Quinine & $\begin{array}{l}\text { Pama- } \\
\text { quine }\end{array}$ & & \\
\hline & & $m g . / L$ & $\mu g . / L$ & & days \\
\hline
\end{tabular}

Group I-Quinine alone

\begin{tabular}{l|r|r|r|r|r}
\hline $\mathrm{Ho}$ & $8+$ & 10.8 & - & 426 & \\
$\mathrm{Bu}$ & $14+$ & 10.3 & - & 12 & \\
$\mathrm{Ba}$ & $11+$ & 8.9 & - & 8 & \\
$\mathrm{St}$ & $10+$ & 8.4 & - & 21 & 4 \\
$\mathrm{Ma}$ & $7+$ & 8.1 & - & & 463 \\
\hline
\end{tabular}

Group II-Quinine and pamaquine (30 mg. daily) concurrently

\begin{tabular}{c|r|r|r|r|r}
\hline & & Quinine & $\begin{array}{c}\text { Pama- } \\
\text { quine }\end{array}$ & & \\
\cline { 2 - 4 } $\mathrm{Ni}$ & $3+$ & 9.1 & 69 & & 331 \\
$\mathrm{Ja}$ & $6+$ & 10.3 & 61 & 361 & \\
$\mathrm{Do}$ & $6+$ & 11.2 & 51 & 10 & 330 \\
$\mathrm{Ha}$ & $11+$ & 7.3 & 41 & & 330 \\
\hline
\end{tabular}

Group III-Quinacrine and pamaquine (30 mg. daily) concurrently

\begin{tabular}{l|r|c|c|c|c}
\hline & & $\begin{array}{c}\text { Quina- } \\
\text { crine }\end{array}$ & $\begin{array}{c}\text { Pama- } \\
\text { quine }\end{array}$ & & \\
\hline $\mathrm{Ca}$ & $12+$ & 66 & 311 & & 334 \\
$\mathrm{Bra}$ & $5+$ & 81 & 290 & & 334 \\
$\mathrm{Bro}$ & $13+$ & 61 & 261 & & 358 \\
$\mathrm{Hu}$ & $8+$ & 69 & 209 & & 314 \\
\hline
\end{tabular}

Group IV-Quinine and pamaquine (90 mg. daily) concurrently

\begin{tabular}{|c|c|c|c|c|}
\hline & & Quinine & $\begin{array}{l}\text { Pama- } \\
\text { quine }\end{array}$ & \\
\hline $\begin{array}{l}\text { Sw } \\
\text { Fl } \\
\text { Le } \\
\text { Bu } \\
\text { Ro } \\
\text { Wi } \\
\text { Cl } \\
\text { Mo } \\
\text { Sc }\end{array}$ & $\begin{array}{r}8+ \\
17+ \\
17+ \\
18+ \\
11+ \\
20+ \\
11+ \\
13+ \\
16+\end{array}$ & $\begin{array}{r}11.2 \\
12.9 \\
10.4 \\
10.6 \\
11.6 \\
10.6 \\
9.3 \\
11.1 \\
9.3\end{array}$ & $\begin{array}{l}264 \\
198 \\
186 \\
178 \\
168 \\
167 \\
154 \\
132 \\
110\end{array}$ & $\begin{array}{l}\mathbf{5 5 2} \\
\mathbf{5 5 5} \\
\mathbf{5 5 1} \\
\mathbf{5 5 2} \\
\mathbf{5 4 7} \\
\mathbf{5 0 8} \\
\mathbf{5 4 8} \\
\mathbf{5 4 8} \\
\mathbf{5 5 1}\end{array}$ \\
\hline
\end{tabular}

Group V-Pamaquine (90 mg. daily) followed by quinine

\begin{tabular}{c|c|c|c|c|c}
\hline & & Quinine & $\begin{array}{c}\text { Pama- } \\
\text { quine }\end{array}$ & & \\
\cline { 2 - 3 } $\mathrm{Br}$ & $9+$ & 5.4 & 265 & & 457 \\
$\mathrm{Go}$ & $13+$ & 9.5 & 112 & & 459 \\
$\mathrm{No}$ & $10+$ & 5.4 & 110 & & 459 \\
$\mathrm{Ed}$ & $12+$ & 5.4 & 76 & 51 & \\
$\mathrm{We}$ & $12+$ & 6.7 & 71 & 55 & \\
\hline
\end{tabular}

* Summation of individual mosquito infection densities. pamaquine was selected as being the most likely to produce a distribution of cures and non-cures based on the information available from the Goldwater studies.

The results of treatment in these two groups are presented in Tables VI and VII. The short and uniform interval between treatment with quinine alone and relapse is strikingly shown in Table VI. The results in this group differ considerably from those obtained in the patients similarly treated at Goldwater Memorial Hospital (Group I, Table V). It is believed that the difference is attributable largely to the heavier sporozoite inoculum used in the Green Haven studies.

The results of treatment with simultaneous pamaquine (60 mg. daily) and quinine differ sharply from those obtained with quinine alone. Although 13 of the 18 subjects had at least one relapse, the interval from treatment to first relapse was markedly prolonged and variable. The incidence of second relapse was markedly reduced and only one-third relapse was observed. Within any group of similarly treated patients there was no relationship between. plasma drug concentration and the occurrence of relapse.

\section{DISCUSSION}

The suppressive action of pamaquine is more marked in vivax than in falciparum malaria but there exists at least as much difference between different strains of falciparum as between vivax and falciparum. However, it is evident that, in doses which approach the maximum tolerated, pamaquine is a relatively ineffective suppressive drug against both vivax and falciparum malaria, being, in general, incapable of effecting a complete interruption of the schizogonous cycle. For this reason, in studies designed to test the curative action of pamaquine, the erythrocytic phase of vivax malaria must be eradicated with a more potent suppressive agent. This is necessary to insure that each recurrence of activity represents a true relapse rather than the appearance of a temporarily suppressed erythrocytic phase.

Pamaquine has a curative action in vivax malaria which is clearly apparent when the drug is given at high dosage, in combination with quinine and for a period of 14 days. Pamaquine administered alone has a curative action but this is not 
TABLE VI

Interval from treatment with quinine to relapse in individuals with sporozoite-induced vivax malaria (Chesson strain) Each attack was treated with 2 grams of quinine (base) daily for 16 days

\begin{tabular}{|c|c|c|c|c|c|c|c|c|c|c|c|}
\hline \multirow[b]{2}{*}{ Patient } & \multirow[b]{2}{*}{ Inoculum } & \multicolumn{2}{|c|}{ Primary } & \multicolumn{2}{|c|}{ 1st relapse } & \multicolumn{2}{|c|}{ 2nd relapse } & \multicolumn{2}{|c|}{ 3rd relapse } & \multicolumn{2}{|c|}{ 4th relapse } \\
\hline & & $\begin{array}{c}\text { Mean } \\
\text { quinine } \\
\text { level }\end{array}$ & $\begin{array}{l}\text { Days } \\
\text { to } \\
\text { relapse }\end{array}$ & $\begin{array}{c}\text { Mean } \\
\text { quinine } \\
\text { level }\end{array}$ & $\begin{array}{c}\text { Days } \\
\text { to } \\
\text { relapse }\end{array}$ & $\underset{\substack{\text { Mean } \\
\text { levinel }}}{\text { Menine }}$ & $\begin{array}{c}\text { Days } \\
\text { to } \\
\text { relapse }\end{array}$ & $\underset{\substack{\text { Muinine } \\
\text { level }}}{\text { Men }}$ & $\begin{array}{c}\text { Days } \\
\text { to } \\
\text { relapse }\end{array}$ & $\underset{\substack{\text { Mean } \\
\text { levinel }}}{\text { evine }}$ & $\begin{array}{l}\text { Days } \\
\text { to } \\
\text { relapse }\end{array}$ \\
\hline $\begin{array}{l}\mathrm{Ci} \\
\mathrm{St} \\
\mathrm{Mo} \\
\mathrm{Pe} \\
\mathrm{Mo} \\
\mathrm{Ra} \\
\mathrm{He} \\
\mathrm{Pa} \\
\mathrm{Wi} \\
\mathrm{Ph} \\
\mathrm{Do} \\
\mathrm{Du}\end{array}$ & $\begin{array}{l}29 \\
22 \\
47 \\
35 \\
28 \\
21 \\
47 \\
47 \\
41 \\
19 \\
21 \\
32\end{array}$ & $\begin{array}{r}\text { mg./L } \\
8.5 \\
8.3 \\
6.8 \\
6.5 \\
6.3 \\
6.1 \\
6.0 \\
5.9 \\
4.9 \\
10.0 \\
7.0 \\
5.8\end{array}$ & $\begin{array}{l}8 \\
9 \\
9 \\
6 \\
9 \\
5 \\
9 \\
9 \\
6 \\
8 \\
9 \\
8\end{array}$ & $\begin{array}{c}m g . / L \\
7.3 \\
6.1 \\
6.1 \\
5.7 \\
4.8 \\
5.0 \\
4.9 \\
4.9 \\
3.5 \\
6.4 \\
6.4 \\
5.5\end{array}$ & $\begin{array}{r}10 \\
8 \\
8 \\
12 \\
13 \\
11 \\
8 \\
10 \\
7 \\
13 \\
9 \\
8\end{array}$ & $\begin{array}{c}m g . / L \\
6.8 \\
5.8 \\
* \\
6.1 \\
4.2 \\
4.5 \\
6.1 \\
5.4 \\
5.4 \\
5.5 \\
5.8 \\
6.0\end{array}$ & $\begin{array}{r}17 \\
13 \\
\\
13 \\
17 \\
11 \\
9 \\
11 \\
7 \\
17 \\
11 \\
12\end{array}$ & $\begin{array}{c}m g . / L \\
* \\
7.6 \\
* \\
5.7 \\
3.4 \\
* \\
5.0 \\
* \\
3.8 \\
* \\
*\end{array}$ & $\begin{array}{r}13 \\
22 \\
9 \\
37 \\
17\end{array}$ & $\begin{array}{c}\text { mg./L } \\
\text { * } \\
\text { * } \\
* \\
* \\
*\end{array}$ & \\
\hline
\end{tabular}

* Study discontinued.

clearly defined by the experimental data presented here (cf. group V, Table V). The data which bear on the curative action of pamaquine also

TABLE VII

Interval from treatment with combined quinine and pamaquine to relapse in individuals with sporozoiteinduced vivax malaria (Chesson strain)

Each attack was treated with 2 grams of quinine (base) daily for two days, followed by concurrent administration of 2 grams of quinine and $60 \mathrm{mg}$. of pamaquine daily for 14 days.

\begin{tabular}{|c|c|c|c|c|c|c|c|c|}
\hline \multirow[b]{2}{*}{$\begin{array}{c}\mathrm{Pa}- \\
\text { tient }\end{array}$} & \multirow[b]{2}{*}{$\begin{array}{l}\text { Inoc- } \\
\text { ulum }\end{array}$} & \multicolumn{3}{|c|}{ Primary attack } & \multicolumn{3}{|c|}{ First relapse } & \multirow{2}{*}{$\begin{array}{c}\text { Observa- } \\
\text { tion } \\
\text { period } \\
\text { (negative } \\
\text { cases) }\end{array}$} \\
\hline & & $\begin{array}{c}\text { Mean } \\
\text { qui- } \\
\text { nine } \\
\text { level }\end{array}$ & $\begin{array}{l}\text { Mean } \\
\text { pama- } \\
\text { quine } \\
\text { level }\end{array}$ & $\begin{array}{c}\text { Days } \\
\text { to } \\
\text { relapse }\end{array}$ & $\begin{array}{c}\text { Mean } \\
\text { qui- } \\
\text { nine } \\
\text { level }\end{array}$ & $\begin{array}{l}\text { Mean } \\
\text { pama- } \\
\text { quine } \\
\text { level }\end{array}$ & $\begin{array}{c}\text { Days } \\
\text { to } \\
\text { relapse }\end{array}$ & \\
\hline $\begin{array}{l}\mathrm{Mc} \\
\mathrm{Mo} \\
\mathrm{Cr} \\
\mathrm{Ro} \\
\mathrm{Ada} \\
\mathrm{No} \\
\mathrm{Adl} \\
\mathrm{Du} \\
\mathrm{Au} \\
\mathrm{Be} \\
\mathrm{Go} \\
\mathrm{St} \\
\mathrm{Di} \\
\mathrm{Si} \\
\mathrm{Do} \\
\mathrm{Tr} \\
\mathrm{Gi} \\
\mathrm{Na}\end{array}$ & $\begin{array}{l}35 \\
35 \\
26 \\
31 \\
32 \\
25 \\
21 \\
29 \\
22 \\
22 \\
54 \\
30 \\
25 \\
19 \\
24 \\
26 \\
37 \\
32\end{array}$ & \begin{tabular}{|c|}
$m g . / L$ \\
7.6 \\
6.2 \\
8.9 \\
7.0 \\
7.8 \\
6.7 \\
5.8 \\
8.5 \\
6.7 \\
6.6 \\
6.5 \\
6.3 \\
5.7 \\
6.5 \\
5.6 \\
8.0 \\
5.2 \\
6.9
\end{tabular} & $\begin{array}{r}\mu g . / L \\
216 \\
208 \\
128 \\
116 \\
109 \\
108 \\
80 \\
72 \\
70 \\
70 \\
67 \\
63 \\
63 \\
62 \\
60 \\
56 \\
42 \\
113\end{array}$ & $\begin{array}{l}62 \\
69 \\
24 \\
\\
67 \\
26 \\
20 \\
\\
22 \\
50 \\
22 \\
47 \\
22\end{array}$ & $\begin{array}{c}m g . / L \\
\\
5.4 \\
7.5 \\
6.8 \\
\\
6.2 \\
4.1 \\
5.8 \\
\\
5.6 \\
4.8 \\
5.3 \\
6.0 \\
5.8\end{array}$ & $\begin{array}{r}\mu g . / L \\
188 \\
105 \\
120 \\
\\
82 \\
48 \\
56 \\
47 \\
53 \\
41 \\
68 \\
62\end{array}$ & $80^{*}$ & $\begin{array}{l}\text { days } \\
256 \\
214 \\
201 \\
251 \\
276 \\
\\
249 \\
250 \\
277 \\
218 \\
199 \\
253 \\
221 \\
248 \\
276 \\
256 \\
215\end{array}$ \\
\hline
\end{tabular}

* Study discontinued.

** This patient had a third relapse, 129 days later; the mean plasma quinine concentration was $4.7 \mathrm{mg}$./L; the mean plasma pamaquine concentration was $71 \mu \mathrm{g} . / \mathrm{L}$. demonstrate that the tendency of vivax malaria to relapse and the time of appearance of the relapse, whether treated with quinine alone or with quinine and pamaquine, are in no small measure determined by the density of the initial infection (sporozoite dosage Tables V, VI, VII). Presumably, this is an important factor in determining the history of the disease when acquired naturally.

The data define the curative dosage of pamaquine for Chesson malaria in terms of the amount required to cure primary attacks resulting from heavy sporozoite dosage. This would appear to be in the range of $60-90 \mathrm{mg}$. of pamaquine base when administered in conjunction with 2.0 grams of quinine for 14 days.

It seems likely that curative effects observed at lower dosages $(8,12)$ are attributable to greater strain susceptibility, to the administration of drug at a later stage of the disease, or to a lesser density of the underlying tissue infection. The latter two circumstances may, in fact, be related. That is, a lesser density of the underlying tissue phase of the disease may result from either a smaller sporozoite inoculum or a diminution with time of an initially high density of tissue parasites.

Contrary to the situation encountered in the study of a number of suppressive antimalarials $(13,14,15)$, there is no correlation between plasma pamaquine concentration and antimalarial effect whether suppressive or curative. Furthermore, a suppressive action is observed at very 
low dosage but is not greatly increased with progressive increases in dosage to a very high level. Of interest in this relation is the observation that pamaquine has activity in developing cultures of erythrocytic parasites only at plasma drug concentrations many times those which are attained with doses in the usual range (16).

\section{SUMMARY}

1. Pamaquine at maximum tolerated doses is incapable of effecting interruption of the erythrocytic schizogonous cycle of vivax and falciparum malaria.

2. Pamaquine has a curative action in primary attacks of sporozoite-induced Chesson strain vivax malaria when the drug is given at high dosage, 60-90 mg. daily, in conjunction with 2.0 grams quinine daily for 14 days.

3. It appears that curative effects observed by other workers at lower dosages are attributable to greater strain susceptibilities, to administration of drug at a later stage of the disease, or to a lesser density of underlying tissue infection.

4. There is no correlation between plasma pamaquine concentration and antimalarial effect whether suppressive or curative.

\section{BIBLIOGRAPHY}

1. James, S. P., Some general results of a study of induced malaria in England. Tr. Roy. Soc. Trop. Med. \& Hyg., 1931, 125, 477.

2. James, S. P., On the prevention of malaria with Plasmoquine. Lancet, 1931, 2, 341.

3. Swellengrebel, N. H., Third general report of the Malaria Commission of the Health Organization of the League of Nations. Quart. Bull. Health Organ., League of Nations, 1933, 2.

4. Sinton, J. A., Smith, S., and Pottinger, D., Studies in malaria with special reference to treatment; further researches into the treatment of chronic benign tertian malaria with Plasmoquine and Quinine. Indian J. M. Research, 1929-30, 17, 793.

5. Third general report of the Malaria Commission of the Health Organization of the League of Nations. Quart. Bull. Health Organ., League of Nations, 1933, 2.
6. Shannon, J. A., Earle, D. P., Berliner, R. W., and Taggart, J. V., Studies on the chemotherapy of the human malarias. I. Method for the quantitative assay of suppressive antimalarial action in vivax malaria. J. Clin. Invest., 1948, 27, Suppl., 66.

7. Feldman, H. R., Packer, H., Murphy, F. D., and Watson, R. B., Pamaquine naphthoate as a prophylactic for malarial infections. Federation Proc., 1946, 5, 244.

8. Thomson, A. M., and Williams, M. W., Treatment of malaria. Lancet, 1945, 2, 249.

9. Earle, D. P., Berliner, R. W., Taggart, J. V., Welch, W. J., Zubrod, C. G., Wise, N. B., Chalmers, T. C., Greif, R. L., and Shannon, J. A., Studies on the chemotherapy of the human malarias. II. Method for the quantitative assay of suppressive antimalarial action in falciparum malaria. J. Clin. Invest., 1948, 27, Suppl., 75.

10. Brodie, B. B., Udenfriend, S., and Taggart, J. V., The estimation of basic organic compounds in biological fluids. IV. Estimation by coupling with diazonium salts. J. Biol. Chem., 1947, 168, 327.

11. Jones, R., Jr., Craige, B., Jr., Alving, A. S., Whorton, C. M., Pullman, T. N., and Eichelberger, L., A study of the prophylactic effectiveness of several 8-aminoquinolines in sporozoite-induced vivax malaria (Chesson strain). J. Clin. Invest., 1948, 27, Suppl., 6.

12. Most, H., Kane, C. A., Lavietes, P. H., London, I. M., Schroeder, E. F., and Hayman, J. M., Jr., Combined quinine-plasmochin treatment of vivax malaria. Effect on relapse rate. Am. J. M. Sc., 1946, 212, 550.

13. Taggart, J. V., Earle, D. P., Berliner, R. W., Zubrod, C. G., Welch, W. J., Wise, N. B., Schroeder, E. F., London, I. M., and Shannon, J. A., Studies on the chemotherapy of the human malarias. III. The physiological disposition and antimalarial activity of the cinchona alkaloids. J. Clin. Invest., 1948, 27, Suppl., 80.

14. Taggart, J. V., Earle, D. P., Berliner, R. W., Welch, W. J., Zubrod, C. G., Jailer, J. W., Kuhn, B. H., Norwood, J., and Shannon, J. A., Studies on the chemotherapy of the human malarias. V. The antimalarial activity of quinacrine. J. Clin. Invest., 1948, 27, Suppl., 93.

15. Berliner, R. W., Earle, D. P., Jr., Taggart, J. V., Zubrod, C. G., Welch, W. J., Conan, N. J., Bauman, E., Scudder, S. T., and Shannon, J. A., Studies on the chemotherapy of the human malarias. VI. The physiological disposition, antimalarial activity, and toxicity of several derivatives of 4aminoquinoline. J. Clin. Invest., 1948, 27, Suppl., 98.

16. Berliner, R. W., Unpublished data. 